\title{
AOR
}

Selected Papers of \#AolR2021:

The 22nd Annual Conference of the

Association of Internet Researchers

Virtual Event / 13-16 Oct 2021

\section{FINNISH RIGHT TO BE -CITIZENS INITIATIVE CAMPAIGN AND THE "FEELING OF BEING COUNTED"}

Valo Vähäpassi

University of Turku

In my research project, I address the Finnish Oikeus olla- (Right to Be) citizens initiative campaign (2021) for a new trans law, from the viewpoint of the felt or anticipated "feeling of being counted" (Coleman 2013; Papacharissi 2015, 25), in several senses, shared and expressed on social media. I address the engagement in the campaign as the affective experience related to taking part in the number (of people) which comes to politically matter. Following Sara Ahmed (Smitchz and Ahmed 2014, 1), I do not separate affect from emotion. Following scholars interested in the meanings and emotions attached with numbers in the current culture (Kennedy and Hill 2018), and the importance of emotions in politics (Coleman 2013; Papacharissi 2015), I am interested in how meanings and emotion are attached to numbers in LGBTIQ politics and activism. I concentrate on the affective aspects of taking part in the initiative and engaging with the online campaign.

I ask, what work online signature count and the growing figures shared online do, when combined with the discourses and action frames of the campaign? How are the anticipation of reaching the required 50000 , following the increasing count, and reaching the threshold of required amount of signatures, lived and shared online?

\section{Background of the Right to Be -citizens initiative campaign}

The Finnish so called trans law (from 2003) has been critiqued by trans activists and human rights organizations for its human rights violations for a long time. The Finnish coalition government of five parties, which has received international attention and admiration for its all-female lead, has its own plans to reform the trans law. However, this planned law is considered highly inadequate by the Finnish trans activists.

Trans activists in Finland have long demanded the separation of juridical gender change from the lengthy medical trans process, which in Finland is a part of the public health care system. According to trans and human rights activists, one of the main faults in the reform planned by Marin's government, is leaving out the under aged. Due to the demands of one party of the coalition government, the center-right party Keskusta, the 
planned law would only allow for juridical change of gender for adults. According to the activists, the reform planned by the government has also other inadequacies, such as not being consistent with the principle of gender self-determination even in the case of adults. Due to these shortcomings, a group of activists, supported by the trans organization Trans.ry, started a citizens initiative for what they call a "just trans law", which would make changing juridical gender a matter of announcement for everyone from the age of 15, and for children under that, a matter of announcement together with their guardian.

Even the proposed law would not address the human rights violations in the medical gatekeeping system for transition related health care. Even while usually presented as a progress for trans rights, a similar bill in another Nordic welfare state, Denmark, has been critiqued of leading to worsening trans people's access to state provided trans healthcare. State recognition of the principle of self-determination over juridical gender can be seen as politics of recognition. However, the lack of self-determination of (juridical) gender also has concrete and material consequences for many trans people.

This background makes it pertinent to address the implications of the politics of recognition at play. It is important to ask, how and to what effect are affective relations to the nation state as well as the imagined nation of trans people lived and enlivened through media.

\section{Method and material}

I address the citizens initiative through media autoetnography (Kyrölä 2014), combined by theoretically informed qualitative analysis of online material related to the campaign. Apart from the autoetnography, I address social media posts by the campaign and its background organization Trans.ry, the campaign website, and the state provided site for signing citizens initiatives.

To address the "affective public" (Papacharissi 2015) gathered around the campaign, I address public posts on Twitter using the campaign hashtag. I address tweets using the campaign hashtag from 6.4-8.4.2021, in other words, the two days it took to gather the required signatories, and one day after that. I use these posts as examples of taking part in the campaign and in the publicly shared experience created by the campaign.

For Instagram material, I address public posts on Instagram by individual party politicians using the campaign hashtag. Even while their parties are in the government, these politicians express their enthusiastic support for the citizen's iniative. I chose politicians public posts for analysis, because of their wider online visibility, and because of their already public status as politicians. Through the publicly expressed feelings about the initiative and issues it tackles, shared discourses, and "action frames" (Bennett and Segerberg 2012), such as the campaign hashtag and the figure 50000 , these posts take part in the campaign.

In the wider project, I will also address the rest of the public Instagram posts using the hashtag \#oikeusolla, and conduct a deeper analysis of the discourses utilized by the campaign on its website and social media. I will possibly also conduct interviews about 
the experience of taking part in the citizens' initiative and of sharing this collective moment online on various platforms. I will continue studying the campaign and the experiences of taking part and sharing feelings and views about it, as the citizen's initiative eventually goes to hearing in the parliament.

\section{On the threshold of being counted}

I address the way the citizens initiative creates both a "feeling of being counted" (Coleman 2013) and a threshold for being counted in the national context, and consider the implications for trans politics. My initial "hypothesis" is that trans rights citizens' initiative as a mode of activism, invigorated by the "sharing" environments of social media, creates a feeling of "communicating to the nation" (Sturken 1997, 14), and a feeling of being at the threshold of being heard and seen by the Finnish nation state. Through the simultaneity of taking part in the counting, and waiting to be counted, through social media, the citizen's initiative campaign also helps create an imagined nation (Anderson 1983) of trans people (and allies), a sort of nation within a nation.

\section{References}

Anderson, Benedict.1983. Imagined Communities: The Origin and Spread of Nationalism. London: Verso.

Bennett, Lance \& Segerberg Alexandra. 2012. The Logic of Connective Action. Information, Communication \& Society, 15(5): 739-768.

Coleman, Stephen. 2013. How Voters Feel. Cambridge: Cambridge University Press.

Kennedy, Helen, and Rosemary Lucy Hill. 2018. The Feeling of Numbers: Emotions in Everyday Engagements with Data and Their Visualisation. Sociology 52, no. 4 (August 2018): 830-48. https://doi.org/10.1177/0038038516674675.

Kyrölä, Katariina. 2014. The weight of Images. Affect, Body Image and Fat in the Media. Ashgate: Farnham \& Burlington.

Schmitz, Sigrid, and Sara Ahmed. 2014. Affect/Emotion: Orientation Matters. A Conversation between Sigrid Schmitz and Sara Ahmed. FZG-Freiburger Zeitschrift für GeschlechterStudien 20.2 (2014): 13-14. https://elibrary.utb.de/doi/pdf/10.3224/fzg.v20i2.17137

Papacharissi, Zizi. 2015. Affective Publics: Sentiment, Technology and Politics. Oxford: Oxford UP.

Sturken Marita. 1997. Tangled Memories: The Vietnam War, the AIDS Epidemic, and the Politics of Remembering. Berkeley: University of California Press. 